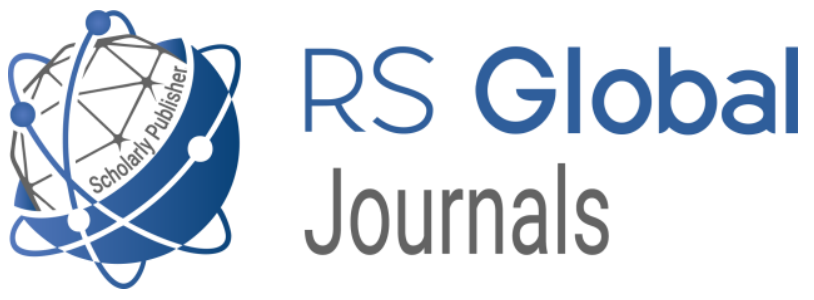

Scholarly Publisher

RS Global Sp. z O.O.

ISNI: 0000000484952390

Dolna 17, Warsaw, Poland 00-773

Tel: +48226022703

Email: editorial_office@rsglobal.pl

JOURNAL International Journal of Innovative Technologies in Social Science

p-ISSN

$2544-9338$

e-ISSN

2544-9435

PUBLISHER

RS Global Sp. z O.O., Poland

ARTICLE TITLE

NETWORKING AS A COMPONENT OF FORMING SOCIAL CAPITAL: THE ECONOMIC ASPECT

$\operatorname{AUTHOR}(\mathbf{S})$

Halushka Zoia, Nafus Inna

Halushka Zoia, Nafus Inna. (2020) Networking as a Component

ARTICLE INFO of Forming Social Capital: The Economic Aspect. International Journal of Innovative Technologies in Social Science. 7(28). doi: 10.31435/rsglobal_ijitss/30122020/7289

DOI

https://doi.org/10.31435/rsglobal_ijitss/30122020/7289

RECEIVED

22 October 2020

ACCEPTED

05 December 2020

PUBLISHED

10 December 2020

(c) (i)

LICENSE

This work is licensed under a Creative Commons Attribution 4.0 International License.

(C) The author(s) 2020. This publication is an open access article. 


\title{
NETWORKING AS A COMPONENT OF FORMING SOCIAL CAPITAL: THE ECONOMIC ASPECT
}

\author{
Halushka Zoia, \\ Doctor of Economics, Professor, Yriy Fedkovich National University of Chernivtsi, Ukraine, \\ Chernivtsi, ORCID ID: https://orcid.org/0000-0003-0597-5221 \\ Nafus Inna, \\ PhD student of the Department of Economic Theory, Management and Administration \\ Yriy Fedkovich National University of Chernivtsi, Ukraine, Chernivtsi, \\ ORCID ID: https://orcid.org/0000-0002-3211-2504
}

DOI: https://doi.org/10.31435/rsglobal_ijitss/30122020/7289

\section{ARTICLE INFO}

Received 22 October 2020

Accepted 05 December 2020

Published 10 December 2020

\section{KEYWORDS}

network society, social network, social capital, forms of social capital, accumulation of social capital.

Jel Codes:

D2, D7, H5, L3, M14, C45

\begin{abstract}
The article analyzes the nature and economic importance of social networks as one of the components of social capital. It is shown that the economic component of social capital is associated with the ability to obtain certain economic benefits from its use. Mechanisms for the accumulation of social capital contain the involvement in these processes of all its components - trust, norms, values, social networks. The network approach of J. Coleman to substantiation of economic essence of social capital is analyzed. The necessity, possibility and directions of influence of social networks on formation and increase of efficiency of social capital have been proved. The types of social networks and the possibilities of their influence on creation of connecting, horizontally-integrating and vertically integrating social capital are revealed. The rating of social networks and examples of their use to increase the efficiency of functioning of social capital are given. It is proved that networks are formed not chaotically, but purposefully, given the subjective vision of the feasibility of such interaction, and their use can have both positive and negative consequences. The possibility of using social networks to form a serviceoriented state is indicated.
\end{abstract}

Citation: Halushka Zoia, Nafus Inna. (2020) Networking as a Component of Forming Social Capital: The Economic Aspect. International Journal of Innovative Technologies in Social Science. 7(28). doi: 10.31435/rsglobal_ijitss/30122020/7289

Copyright: (c) 2020 Halushka Zoia, Nafus Inna. This is an open-access article distributed under the terms of the Creative Commons Attribution License (CC BY). The use, distribution or reproduction in other forums is permitted, provided the original author(s) or licensor are credited and that the original publication in this journal is cited, in accordance with accepted academic practice. No use, distribution or reproduction is permitted which does not comply with these terms.

Raising the problem. Networking approach to the formation of social capital was initiated by American sociologist J. Coleman. In particular, he noted that “... social capital is a collection of real or potential resources that is associated with owning a stable network of more or less institutionalized relationships of mutual acquaintance and recognition, that is, group membership. The latter gives its members resistance in the form of collective capital" [1, p. 102-103]. In economic terms, the following important points of his theory can be noted in terms of substantiation of the essence, structure and sources of social capital formation:

- it is a characteristic of the structure of relationships between actors (individuals, organizations;

- is related to establishing and maintaining relationships between economic entities that give rise to certain actions, and therefore provides for the fulfillment of obligations;

- the more commitments accumulated in a particular community, the higher the level of trust and the higher the level of social capital; 
- networks form the structural basis of the social captcha, important for transmitting information, improving access to resources, forming rules for economic behavior, creating an image of the organization;

- criteria for assessing the level of social capital are: trust, life satisfaction, social identification, etc.;

- there is a link between different levels of social capital accumulation, which shows the dependence of individual social capital on the level of satisfaction of social needs;

- although social capital is a public good, it requires individual investment;

- social capital is an economic resource.

Generalization of modern approaches to the definition of the essence of social capital makes it possible to distinguish its characteristics, the emergence of which is closely linked to the formation of social networks [2]:

- social capital can be regarded as “... a set of real and potential resources associated with owning a stable network of more or less institutionalized relationships of mutual acquaintance and recognition - in other words, with group membership" [3];

- Social capital is the result of the functioning of social networks of interpersonal interactions on the basis of historically determined cultural values and norms.

- other resources may be invested in social capital in anticipation of future returns on investment;

- to some extent, it can be converted to other forms of capital, because social networks and their attributes - connections, obligations, trust - can provide financial and material benefits;

- it can be applied in different directions because the same social network of individuals can provide them with access to different resources and values;

- Networks, norms and trust - which encourage participants to work together more effectively to achieve common goals;

- Active use of social capital by some members of the network at the expense of others may reduce the amount of social capital reproduced by the social network as a whole.

Modern concepts of social space T. Lukman, P. Berger, J. Moreno, N. Miller and other researchers define social networks as "the concept of information and communication society contribute to the development of the UK, which is a fundamental component of a democratic society and market economy" [4]. Networking helps to establish effective economic relationships between different organizations (institutions) - it is an innovative technology, according to which "... not only is the spread of innovative developments, but also there is a process of dialogue between different institutions and the process of reflecting in them the experience of each other" [5]. The network allows to establish a large number of direct contacts immediately and almost without unnecessary expenses of time, effort and energy and thus facilitates the identification of partners [6]. This is facilitated by the development of media and new types of communication. Yes, modern digitization has led to the rapid spread of online internet communications that can completely offset any geographical barriers to establishing social connections and creating social capital on a global scale.

Social network is defined as a circle of agents (people), where the agents themselves are centers of social networks, and their acquaintances (connections) build network branches, engaging in social relations [7, p.54]. Modern networks form their own "architecture", are made up of a large number of separate entities, interconnected, and based on business agreements, exchange of information and services. This is a relatively new phenomenon in terms of the accumulation of modern forms of social capital as an economic resource, so it is rather fragmented in scientific economic research and needs some clarification.

The purpose of the article is to determine the directions of influence of social networks on the formation of connecting, horizontally-integrating and vertically-integrating social capital as an economic resource of participants of these networks.

Methodology. On the basis of generalization and comparison of theoretical concepts of social capital, its economic component is determined. Structural analysis of social capital made it possible to identify some areas of influence of social networks on its formation.

Presenting main material. Modern network society is a type of information society, where a new complex system of interaction between individual citizens, the state and society is formed. Networks have become the most modern projects of interaction in all spheres of economy and public 
relations, able to replace the former hierarchical structures. They carry information and knowledge, allow many participants to participate in decision-making, allow for informal relationships, ensure organizational integrity without forming structural divisions, and generate nonlinearity of social and economic development. Networks are composed at different levels of the functioning of the economy. The modern model of a service-oriented state is not imagined without the existence of communication networks providing close interconnection and interaction between public authorities, business structures and citizens. From our point of view, in Ukraine today networks play a decisive role in implementing decentralization processes, forming united territorial communities. It is also difficult to overestimate the importance of business networks, especially for marketing. The most popular networks in Ukraine (according to the 2019 rating) are Facebook, which has 2.2 billion active users per month, as well as: YouTube - 1.9 billion, WhatsApp - 1.5 billion, Messenger - 1.3 billion, WeChat - 1.06 billion, Instagram - 1 billion, QQ - 861 million, Qzone - 632 million, etc.) [8]. These networks are used not only by ordinary citizens, but also by millions of companies that develop and deploy their business platforms, send information to potential partners and customers, make purchases, and more.

Social boundaries include both the actors themselves (network members) and the components of their interaction (social and political interests, power relations, collective action, compatible principles, rules, rules of engagement).

There are several important areas of influence of networking on the formation of IC [9].

- the network facilitates the identification of partners, effectively establishes communications;

- due to information and communication technologies, network barriers are eliminated;

- public networks - form a horizontal structure of communications;

- access to databases of scientific data and information on enterprises and organizations;

- there is a saving on transaction costs;

- networking ensures access, variability and openness of education;

- the Internet provides support for counterparty interaction;

- An interactive principle of political interaction is built on the basis of networks;

The peculiarities of the influence of networks on the formation of social capital can be explained by the fact that:

1) The network structure allows for effective communication and, consequently, for sharing experiences of problem solving in communities, and in addition, responding to the needs of emerging communities in a timely manner. Internet technologies, with adequate freedom and access to a network structure devoid of space and time constraints, allow to establish a considerable number of direct contacts. This helps to solve many socio-economic problems, such as employment problems. Networks provide access to databases of scientific data and information on the activities of enterprises, organizations, institutions, individual scientists, etc. The Internet acts as a single large market with a low entry barrier and a level playing field. Internet technologies make it possible to create and maintain interactive interactions between channel and customer channels - they have become a tool for dialogue with buyers and contractors. Regular buyers are part of the virtual distribution infrastructure, simultaneously the source and destination of communications.

2) Networking is important for joint learning, promotion of various services, etc. For example, in the education system it allows: to distribute resources in the overall task of the activity; rely on the initiative of each individual participant; direct contact of participants with each other; to build various possible ways of movement with the common external purpose; use the shared network resource for the needs of each individual participant. Networking is becoming one of the powerful resources of innovative education, it helps to find precedents, get expertise of their own developments, expand the list of educational services for students, including through the implementation of educational programs in a network form.

3) Networking is nowadays becoming a modern, highly innovative technology that not only disseminates innovative developments. The network allows to establish a large number of direct contacts instantly and almost without unnecessary expenses of time, effort and energy and thus facilitates the identification of partners [6].

4) The network principle is also used to improve the direct management of organizations. The so-called Public Networks - form a horizontal structure of communications. According to researchers, the effectiveness of organizations built on this principle is guaranteed by the low level of employment and rational cost structure $[10$, p. 86]. 
5) On the basis of network structures, an interactive principle of political interaction is also being built, which is "... implemented through innovative media technologies through social networks (virtual communities, websites, Internet versions and social media pages of television and radio channels) and interactive programs that make it possible for the public to communicate with politicians, officials, experts" [11, p. 152].

6) Thanks to information and communication technologies, the barriers of space are eliminated in the networks, the ability to move virtual without direct physical physical activity is created, which in some way reduces the real territorial mobility [12].

7) Existence, observance and restoration of relationships are supported by the means of the social network itself, such as: tangible and intangible resources available to it; Public Opinion; social connections; channels of information exchange.

8) Networks will focus on the accumulation of individual social capital. Yes, in a network, the value of a person's position is determined by the number and quality of their relationship. High levels of connectivity, access and status give individual participants unique power to capitalize on their capabilities through enrichment and the implementation of profitable ideas. This is how superhabs are formed. Connection with them is desirable because such a relationship creates a status that can be used to pursue specific interests. Status - determines a person's place in society, his / her prestige, authority and dominance, influence, power, etc.

The spread of social capital in networks is based on social ties, which characterize the various possibilities of its accumulation and have the following three forms of social capital: a) connecting, b) horizontally-integrating, c) vertically-integrating [13].

Bonding social capital is characterized by a set of strong social ties and the corresponding normative-value system. It forms a relatively closed structure, defines the close nature of the interaction of individuals within its boundaries, characteristic of family-family groups, groups of close friends, closed elite clubs, etc. Strong social ties, trust and commitment within such groups ensure a high level of mutual support and imply the existence of appropriate commitments by members to the group. The role of social networks in forming a cohesive social capital is to maintain the totality of interconnections between network members, which allows us to formulate common goals and provide mutual support in the process of their realization.

- regular customers become part of the virtual distribution infrastructure;

- internet marketing is becoming a tool for counterparty dialogue.

Horizontally-integrating social capital is a set of weak, mainly horizontal ties and corresponding normative-value system, connecting individuals belonging to different particular groups. Weak social bonds are constructed and maintained both on the basis of rational calculation and on the basis of shared interests and joint activities. They are underpinned by the confidence, mutual expectations and sanctions created by the experience of successful engagement of the participants. Such connections can be made between representatives of one social strata of the population, one professional sphere of activity, who have the same mechanisms of functioning (formally established forms of interaction, frames of professional activity, problems, etc.). Networks allow you to maintain awareness within such groups, create platforms for communication while solving similar problems), and are a precondition for professional collaboration.

Vertically-integrating social capital is a set of weak social ties, spanning different levels of social, economic and power hierarchy and underpinned by a normative and value system common to interconnected entities. In particular, it occurs in the corporate sector, where social networks are an instrument of internal communication. Examples are the use of Workplace's corporate communications platform to systematize the work of HR managers and direct them to the overall result, or "talent management" technologies that enable them to formulate, in accordance with the strategic goals of the organization, the qualification criteria for the professionals who are to implement them.

At the macro level, it is believed that vertically integrating social capital, overcoming power barriers, makes institutional resources and benefits more accessible. For social networks, the basis of consolidation of which is vertically-integrating social capital, is also characterized by another type of non-market exchange - exchange within the system "patron - client". In such networks, negative social capital often arises. Unequal access to resources and status differences between members of the social network in the patronage system allow for the exchange of benefits in the form of two counter flows. The first flow is the distribution of resources and other benefits from the patron to the customer. The 
second flow is the relocation of some of the subordinates' resources, as well as the provision of services and demonstration of customer loyalty to the patron.

Conclusions. Formation and accumulation of social capital is one of the laws of socialization of the modern economy. The economic component of social capital has to do with the potential to receive some economic benefits from its use. Mechanisms of social capital accumulation imply involvement in these processes of all its components - trust, norms, values, social networks. The role of social networks is in their ability to establish a system of direct, horizontal and vertical communications that are important to enhance the effectiveness of collaborative engagement to address common needs and interests. Networks are created not purposefully, but purposefully, given the subjective vision of the expediency of such interaction. Their use can have both positive and negative consequences.

In our view, the prospects for further development in this area should be linked to the scientific justification of the broader opportunities, perspectives and implications of using different networks to improve their social performance.

\section{REFERENCES}

1. Coleman, J. (1990) Foundations of Social Theory. Cambridge MA: Harvard University Press. 1014 p. Retrieved from https://books.google.com.ua/books?id=a4Dl8tiX4b8C\&printsec=frontcover\&hl=ru\&source=gbs_ge_summ ary_r\&cad $=0 \# \mathrm{v}=$ onepage $\& \mathrm{q} \& \mathrm{f}=$ false

2. Ostrom, E. (2000) Social capital: A fad or fundamental concept? // Social Capital: A Multifaceted Perspective / ed. by P. Dasgupta, I. Seragilden. Washington, D.C.: The World Bank, P. 172-214.

3. Bourdieu, P. The Forms of Capital. Handbook of Theory and Research for the Sociology of Education / in Richardson, John G., ed. New York: Greenwood, 1986. P. 241-258.

4. Berger P. Lukman T. Social construction of reality M.: MEDIUM, 1995. 323 c. Retrieved from https://evolkov.net/soc. psychol/Berger.P.Luckmann.T/

5. Miller, N. A. (2012) Osvitniy District: osnovni zavdannya that funktsii. Narodna Osvita. №3(18).

6. Castells, M. (2009) The Power of Identity. Information Age: Economy, Society and Culture. Blackwell Publishing, $584 \mathrm{p}$.

7. Didyk, L.A. (2018) Spatial Disposition of Communication Agents on Social Networking. THE GRANDS. Volume 21. № 6. SOCIOLOGY p.51-57.

8. The most popular social networks in the world. Retrieved from https://futurenow.com.ua/21najpopulyarnishyh-sotsialnyh-merezh-svitu-ta-rejtyngukrayiny/

9. Roundtable on Network Society: Labor Market, Public Relations, the Role of Trade Unions (Kyiv, APSVT, March 22, 2018). Retrieved from https://www.socosvita.kiev.ua/node/2053

10. Shadrin A.E. (1999) Network model of organization. Information Society. No. 2. P.86-88. Retrieved from http://emag.iis.ru/arc/infosoc/emag.nsf /BPA/d0b0d7d739149 c71c32569e500517ce0

11. Vilchinskaya I. (2015) Political interactivity. The latest political vocabulary (neologisms, Occasionalism and other innovations). Encyclopedic Dictionary Directory. For the title. ed. NM Khomi. L.: New World-2000.

12. Masuda Y. (1981) The Informational Society as Postindustrial Society. World Future Society. 165 p. Retrieved from https://books.google.ru/books?id=ynkmIxF1G3AC\&pg=

PR3\&hl=uk\&source=gbs_selected_pages\&cad=2\#v=onepage $\& q \& \mathrm{f}=$ false

13. Granovetter M. (1983) The Strength of Weak Ties Network Theory. Revisited. Sociological Theory. Vol 1. P. 201-233. 